\title{
Supervisi Akademik untuk Meningkatkan Kompetensi Guru Dalam Proses Pembelajaran di SD
}

\section{*Desak Ketut Sitaasih ${ }^{1}$}

${ }^{1}$ SD Negeri 1 Kalibukbuk

\author{
A R T I C L E I N F O \\ Article history: \\ 1 Maret 2020 Received in \\ revised form \\ 30 Maret 2020 \\ Accepted 11 April 2020 \\ Available online 15 \\ Mei 2020

Kata Kunci:
supervisi akademik,
kompetensi proses
pembelajaran
Keywords:
academic supervision,
teachers' competence in the
learning process.

\begin{abstract}
A B S T R A K
Kompetensi guru dalam proses pembelajaran di kelas senyatanya masih rendah, guru kurang mempersiapkan perangkat pembelajaran sebelum masuk di kelas serta pola pikir yang masih kovensisoanal. Penelitian tindakan sekolah ini bertujuan untuk meningkatkan kompetensi guru dalam proses pembelajaran di Sekolah Dasar melalui penerapan supervisi akademik. Subjek penelitian ini adalah guru SD yang jumlahnya 9 orang Penelitian ini meruapakan penelitian tindakan sekolah dilaksanakan dalam 2 siklus, dengan rancangan masingmasing siklus terdiri dari perencanaan, pelaksanaan, observasi/evaluasi dan refleksi. Data dikumpulkan dengan metode observasi. Data yang sudah dikumpulkan dianalisis dengan metode statistic deskriptif. Setelah data kompetensi guru dalam proses pembelajaran dianalisis terlihat peningkatan yang cukup signifikan. Pada prasiklus tingkat kompetensi guru dalam proses pembelajaran sebesar $65,19 \%$ yang tergolong cukup, pada siklus II menjadi $68,06 \%$ yang tergolong cukup,
\end{abstract} dan pada siklus II menjadi $78,06 \%$ yang tergolong baik. Berdasarkan peningkatan tersebut dapat disimpulkan bahwa penerapan supervisi akademik dapat meningkatkan kompetensi guru dalam proses pembelajaran di SD. Dengan adanya supervisi Akademik membantu guru-guru untuk meningkatkan kopetensi pedagogiknya.

\begin{abstract}
A B S T R A C T
The teachers' competence in the learning process in the classroom is actually still low, teachers are less prepared for learning tools before entering the classroom as well as conventional model. This action research aims to improve teachers' competency in the learning process in elementary schools through the application of academic supervision. This research was conducted in two cycles with the design of each cycle consisted of planning, implementation, observation and reflection. A significant improvement can be seen after analyzing the teachers' competency data in the learning process. On the pre-cycle, the level of teachers' competency in the learning process of $65.19 \%$ which was categorized into quite enough, in the first cycle to $68.06 \%$ was quite sufficient and in the second cycle to $78.06 \%$ which was quite good. Based on these improvements it could be concluded that the application of academic supervision could improve teachers' competency in the learning process at school and academic supervision helped teachers to improve pedagogical competence.
\end{abstract}

\section{Pendahuluan}

Salah satu kompetensi yang harus dimiliki dan dikuasai kepala sekolah sebagai supervisor pembelajaran di kelas senyatanya yaitu supervisi akademik (Peraturan Menteri Pendidikan dan kebudayaan No. 13 Tahun 2007). Oleh sebab itu kepala sekolah harus memahami konsep-konsep supervisi akademik, sebagai landasan keilmuan tugas kepala sekolah. Dengan memahami konsep-konsep supervisi akademik diharapkan Kepala sekolah dapat melaksanakan tugas sebagai supervisor secara profesional sehingga bermuara kepada peningkatan kemampuan profesional guru yang menjadi tanggung jawab kepala sekolah. Apabila kepala sekolah dan guru mata pelajaran/guru kelas yang dibina mampu berkolaborassi dan berinterakksi secara sinergi maka akan berdampak terhadap peningkatan mutu pembelajaran dalam proses pembelajaran di kelas senyatanya. Dan ini membuktikan bahwa kepala sekolah sebagai mitra kerja dengan guru di sekolah binaannya dalam proses pembelajaran.

Copyright (@) Universitas Pendidikan Ganesha. All rights reserved 
Untuk melaksanakan supervisi akademik secara efektif diperlukan keterampilan konseptual, interpersonal dan teknikal (Glickman dalam Masnun, 2017). Oleh sebab itu, setiap Kepala sekolah harus memiliki keterampilan teknikal berupa kemampuan menerapkan teknik-teknik supervisi yang tepat dalam melaksanakan supervisi akademik. Teknik-teknik supervisi akademik meliputi dua macam, yaitu: individual dan kelompok. Supervisi akademik harus secara langsung mempengaruhi keadaan lingkungan perilaku guru dalam mengelola kelas pada proses pembelajaran dimana guru secara langsung maupun tidak langsung mengubah mindset mereka dalam menyampaikan materi pembelajaran pada kegiatan pendahuluan, kegiatan inti, maupun kegiatan penutup. Kompetensi guru yang mampu mengubah mindsetnya terlihat pada tahap-tahap pembelajaran (Usman, 2018). Menurut Zulfikar, Yusrizal, (2017) pelaksanaan supervisi akademik oleh kepala sekolah dapat meningkatkan proses pembelajaran jika dilakukan sesuai dengan prinsip-prinsip yang berlaku. Oleh karena itu, kepala sekolah sebagai supervisor dituntut untuk mampu melakukan supervisi akademik bagi guru-guru dalam meningkatkan proses pembelajaran.

Guru harus mampu membangkitkan motivasi belajar peserta didik, dan mengedepankan proses elaborasi sehingga perilaku peserta didik yang hendak diukur dapat terlihat dan muncul selama proses pembelajaran dengan mengambil prinsip belajar peserta didik aktif. Tingkat kemampuan, kebutuhan, minat, dan kematangan profesional serta karakteristik personal guru harus dijadikan dasar pertimbangan dalam pengembangan dan mengimplementasikan program supervisi akademik khususnya dalam proses pembelajaran di kelas senyatanya. Dalam usaha untuk memperbaiki dan meningkatkan proses pembelajaran yang dilakukan oleh guru, kepala sekolah bertugas menyelenggarakan serta melaksanakan kegiatan supervisi. Tugas ini cukup penting karena melalui peran supervisor, kepala sekolah dapat memberi bantuan, bimbingan, ataupun layanan kepada guru dalam menjalankan tugas ataupun dalam memecahkan permasalahan yang dihadapi pada saat proses pembelajaran (Suradi, 2018).

Kondisi nyata yang terjadi di SD Negeri 1 Kalibukbuk sebelum diadakan tindakan dalam upaya mengubah mindset guru dari pola belajar guru aktif (guru sentris) ke pola belajar peserta didik aktif. Faktor Penyebab kondisi pembelajaran di kelas yang masih belum sesuai dengan Permendikbud No. 22 Tahun 2016 tentang Standar Proses ini antara lain pembiasaan guru yang sudah membudaya, kompetensi guru dalam proses pembelajaran di kelas senyatanya masih rendah, guru kurang mempersiapkan perangkat pembelajaran sebelum masuk di kelas, guru belum mampu merubah mindset cara mengajar kearah pembelajaran yang berbasis peserta didik aktif, dan alasan-alasan lain yang bersifat konvensional seperti guru yang berpendapat yang penting mengajar dengan metode apa saja yang tidak terlalu ruwet dan materi pembelajaran selesai walaupun belum tuntas.

Solusi yang bisa dilakukan oleh kepala sekolah selaku peneliti sebenarnya banyak antara lain mengefektifkan KKG, mengadakan workshop terkait dengan penyusunan RPP yang baik dan benar dan tata cara mengajar yang mengarah kepada kegiatan peserta didik aktif, mengadakan mikro teaching dan riil teaching dalam proses pembelajaran yang mengarah kepada kegiatan eksplorasi, elaborasi, dan komfirmasi, dan mengefektifkan supervisi dalam proses pembelajaran bagi guru kelas yang dititik beratkan pada tata cara mengajar yang baik dan benar di kelas senyatanya. Melalui supervisi, para guru sebagai pelaku utama dalam penyelenggaraan sistem pendidikan dapat dibantu pertumbuhan dan perkembangan profesinya bagi pencapaian tujuan pembelajaran (Istianah, 2019).

Dengan mengefektifkan pelaksanaan supervisi akademik yang terfokus pada kegiatan proses pembelajaran diharapkan mampu meningkatkan kompetensi guru SD Negeri 1 Kalibukbuk dalam mengelola kegiatan pembelajaran kearah peserta didik aktif. Dari beberapa solusi yang bisa dilakukan oleh peneliti, alternatif yang paling strategis dan bisa merangkum dari semua solusi adalah dengan mengefektifkan pelaksanaan supervisi akademik yang terfokus pada pelaksanaan proses pembelajaran di kelas senyatanya.

Setiap kepala sekolah/madrasah dan pengawas sekolah harus memiliki dan menguasai konsep supervisi akademik yang meliput: pengertian, tujuan dan fungsi, prinsip-prinsip, dan dimensi-dimensi substansi dari supervisi akademik. Supervisi akademik adalah merupakan kegiatan terencana yang ditujukan pada aspek kualitatif sekolah dengan membantu guru melalui dukungan evaluasi pada proses pembelajaran yang dapat meningkatkan hasil belajar (Messi, Wiwin Anggita Sari, 2018)

Supervisi akademik adalah serangkaian kegiatan membantu guru mengembangkan kemampuannya mengelola proses pembelajaran untuk mencapai tujuan pembelajaran (Daresh dalam Sugiyanti \& Sabar Narimo, 2016). Supervisi akademik tidak terlepas dari penilaian kinerja guru dalam mengelola pembelajaran. Sagala (2020) menegaskan bahwa refleksi praktis penilaian kinerja guru dalam supervisi akademik adalah melihat kondisi nyata kinerja guru. Secara konseptual, supervisi akademik adalah serangkaian kegiatan membantu guru mengembangkan kemampuannya merencanakan dan mengelola proses pembelajaran demi pencapaian tujuan pembelajaran. 
Tujuan supervisi akademik adalah membantu guru mengembangkan kemampuannya mencapai tujuan pembelajaran yang dicanangkan bagi murid-muridnya (Riyanto, 2015) Menurut Sukarmen (2018) tujuan supervisi adalah untuk meningkatkan kualitas proses pembelajaran agar menjadi lebih baik. Melalui supervisi akademik diharapkan kualitas akademik yang dilakukan oleh guru semakin meningkat (Dirjen PMPTK, 2008). Pengembangan kemampuan tidak hanya ditekankan pada peningkatan pengetahuan dan keterampilan mengajar guru, tetapi juga pada peningkatan komitmen (commitmen) atau kemauan (willingness) atau motivasi (motivation) guru, sebab dengan meningkatkan kemampuan dan motivasi kerja guru, kualitas pembelajaran akan meningkat. Inti dari dimensi supervisi akademik adalah dalam rangka membina guru untuk meningkatkan mutu proses pembelajaran (Lalupanda, 2019).

Berdasarkan teori yang dikemukakan diatas, maka supervisi akademik adalah kegiatan terencana yang ditujukan pada aspek kualitatif sekolah dengan membantu guru melalui dukungan evaluasi pada proses pembelajaran yang dapat meningkatkan hasil belajar. Supervisi akademik dapat meningkatkan kompetensi guru dalam proses pembelajaran, karena supervisi akademik merupakan suatu bentuk bimbingan atau bantuan profesional yang diberikan kepada guru berdasarkan kebutuhan guru melalui siklus yang sistematis. Guru dalam melaksanakan proses pembelajaran memerlukan bimbingan agar mampu melaksanakan proses pembelajaran sesuai dengan aturan yang berlaku. Melalui supervisi akademik bantuan yang diberikan kepada guru tidak bersifat instruksi atau memerintah, sehingga diharapkan adanya kesediaan untuk menerima perbaikan. Suasana dalam pemberian supervisi adalah suasana yang penuh kehangatan, kedekatan, dan keterbukaan.

Rumusan masalah dalam penelitian ini adalah apakah penerapan supervisi akademik dapat meningkatkan kompetensi guru dalam proses pembelajaran di SD Negeri 1 Kalibukbuk semester II tahun pelajaran 2019/2020? Tujuan penelitian ini adalah untuk meningkatkan kompetensi guru dalam proses pembelajaran di SD Negeri 1 Kalibukbuk semester II tahun pelajaran 2019/2020 setelah penerapan supervisi akademik.

\section{Metode}

Penelitian yang dilakukan termasuk penelitian tindakan. Menurut Agung (2010), penelitian tindakan adalah suatu bentuk penelitian refleksi diri yang dilakukan oleh para partisipan dalam situasisituasi sosial untuk memperbaiki praktik yang dilakukan sendiri. Dengan demikian, akan diperoleh pemahaman yang komprehensif mengenai praktik dan situasi di mana praktik tersebut dilaksanakan.

Prosedur penelitian sangat tergantung dari model penelitian tindakan yang diterapkan.Berkaitan dengan model penelitian tindakan seperti tersebut maka prosedur pelaksanaan tindakan setiap siklusnya secara berdaur meliputi langkah-langkah sebagai berikut.

Penelitian didahului dengan mengidentifikasi permasalahan berdasarkan kondisi nyata pada kompetensi guru dalam proses pembelajaran. Setelah permasalahan teridentifikasi langkah selanjutnya adalah menganalisis permasalahan dimaksud.Analisis masalah dipergunakan untuk merancang tindakan baik dalam bentuk spesifikasi tindakan, keterlibatan peneliti, waktu dalam satu siklus, indikator keberhasilan, peningkatan sebagai dampak tindakan, dan hal-hal yang terkait lainya dengan pemecahan yang diajukan.

Langkah selanjutnya setelah masalah dirumuskan secara operasional, dan telah dirumuskan pula alternatif tindakan yang akan diambil, maka kegiatan selanjutnya adalah merencanakan langkah-langkah tindakan berdasarkan alternatif tindakan yang diambil. Secara rinci, tahapan perencanaan tindakan terdiri atas kegiatan-kegiatan yaitu menentukan cara yang tepat untuk menanggulangi permasalahan yang terjadi dengan menjabarkan indikator-indikator keberhasilan, menetapkan instrumen yang akan dipergunakan, dan mengadakan pertemuan awal untuk membuat kesepakatan mengenai pelaksanaan supervisi akademik.

Pada tahapan pelaksanaan tindakan, rancangan strategi dan skenario supervisi akademik yang telah direncanakan sebelumnya, selanjutnya diimplementasikan terhadap guru SD Negeri 1 Kalibukbuk. Penerapan skenario tindakan dilaksanakan secara benar dan tampak berlaku secara alamiah wajar.

Tahap pengamatan/observasi dan pengumpulan data berlangsung secara bersamaan pada saat pelaksanaan tindakan. Pengamatan dilakukan pada waktu tindakan sedang berjalan, keduanya berlangsung dalam waktu yang sama. Pada tahapan ini, peneliti melakukan pengamatan dan mencatat semua hal-hal yang diperlukan dan terjadi selama pelaksanaan tindakan berlangsung. Pengumpulan data ini dilakukan dengan menggunakan format observasi/penilaian yang telah disusun. Termasuk juga pengamatan secara cermat pelaksanaan skenario tindakan dari waktu ke waktu dan dampaknya terhadap kompetensi guru dalam proses pembelajaran.

Tahap refleksi dimaksudkan untuk mengkaji secara menyeluruh tindakan yang telah dilakukan, berdasar data yang telah terkumpul, dan kemudian melakukan evaluasi guna menyempurnakan tindakan 
yang berikutnya.Refleksi dalam penelitian tindakan, mencakup analisis, sintesis, dan penilaian terhadap hasil pengamatan atas tindakan yang dilakukan. Refleksi bermanfaat untuk mengetahui tingkat keunggulan maupun kelemahan pelaksanaan tindakan yang direncanakan dari masing-masing siklus, sehingga dengan demikian berdasarkan hasil refleksi dapat diputuskan apakah siklus dilanjutkan atau dihentikan. Siklus dilanjutkan bisa karena hasilnya belum mencapai target yang ditentukan. Sedangkan dihentikan jika target telah terpenuhi atau sangat tidak mungkin untuk dilanjutkan. Pada prinsipnya hasil refleksi dipergunakan untuk menyempurnakan kelemahan-kelemahan pelaksanaan tindakan.

Penelitian ini dilakukan dalam 2 (dua) siklus karena pada siklus ke-2 hasil penelitian telah mencapai indikator keberhasilan. Tiap siklus dilaksanakan sebanyak 3 kali pertemuan. Subjek penelitian ini adalah guru SD Negeri 1 Kalbukbuk yang jumlahnya 9 orang.Yang menjadi objek penelitian ini adalah kompetensi guru dalam proses pembelajaran. Penelitian ini dilakukan pada semester genaptahun pelajaran 2019/2020 yakni dari bulan Januari sampai dengan Maret 2020.

Data penelitian ini dikumpulkan dengan menggunakan metode pengamatan/observasi terhadap proses pembelajaran. Kompetensi guru dalam proses pembelajaran akan terukur dari hasil observasi di kelas pada saat guru mengajar. Jika kompetensi guru dalam proses pembelajaran tinggi maka tentu saja nilai dokumen hasil kerja guru akan tinggi juga. Instrumen yang digunakan dalam penelitian ini yang berupa format validasi melaksanakan proses pembelajaran yang disusun dan digunakan oleh tim pengembang kurikulum Kabupaten Buleleng.

Setelah data dalam penelitian ini terkumpul, selanjutnya dianalisis menggunakan analisis statistik deskriptif. Tingkat kompetensi guru dalam proses pembelajaran dapat ditentukan dengan membandingkan M (\%) atau rata-rata persen ke dalam PAP skala lima dengan kriteria yang di jabarkan dalam tabel 01 berikut.

Tabel 01. Pedoman Konversi Skala Lima

\begin{tabular}{c|c}
\hline Persentase (\%) & Kriteria \\
\hline $90-100$ & Sangat Baik \\
$75-89$ & Baik \\
$65-74$ & Cukup \\
$40-64$ & Kurang \\
$0-39$ & Sangat Kurang \\
\hline
\end{tabular}

Sumber: Dantes (2009)

Untuk mengetahui tingkat keberhasilan yang dapat dicapai pada sebuah tindakan, maka perlu ditentukan kriteria keberhasilan yang dapat diamati dari indikator-indikator ketercapaian. Kriteria keberhasilan penelitian ini dapat diukur dari ketercapaian peningkatan kompetensi guru dalam proses pembelajaran, setelah pelaksanaan supervisi akademik. Penelitian ini dikatakan berhasil apabila kompetensi guru dalam proses pembelajaran secara individu telah mencapai rata-rata $\geq 75$, dan tingkat kompetensi guru dalam proses pembelajaran sebesar $75 \%$ yang berada pada kategori baik.

\section{Hasil dan pembahasan}

Ketika dilaksanakan observasi proses pembelajaran sebelum penelitian, tampak guru aktif sendiri. Siswa duduk mendengarkan penjelasan guru dan mengerjakan soal. Siswa hanya mendengarkan guru menjelaskan materi, kemudian mengerjakan tugas yang diberikan guru, dan pelajaran berakhir. Tidak tampak keaktifan siswa dalam mengikuti proses pembelajaran. Berdasarkan data awal diperolah ratarata kompetensi guru dalam proses pembelajaran sebesar 65,19 dengan persentase sebesar 65,19\% yang berarti ingkat kompetensi guru dalam proses pembelajaran berada pada rentangan 65-74 yang tergolong cukup. Untuk meningkatkan kompetensi guru dalam proses pembelajaran dilakukan melalui penerapan supervisi akademik.

Pada siklus I semua guru SD Negeri 1 Kalibukbuk mempersiapkan segala sesuatunya berkaitan dengan tindakan yang akan dilaksanakan. Dimulai dengan menentukan materi ajar, membuat rancangan pembelajaran, menentukan sumber belajar, menentukan dan membuat media dan alat peraga yang diperlukan. Pada pertemuan awal atau pertemuan pendahuluan menghasilkan kesepakatan-kesepakatan tentang identifikasi kesulitan yang dialami dan dihadapi guru dalam melaksanakan proses pembelajaran dan faktor penyebabnya dan menentukan alternatif pemecahannya. Sesuai dengan jadwal yang telah ditentukan pada pertemuan awal langkah kedua dari supervisi akademik adalah guru mengajar dan kepala sekolah mengamati perilaku guru dalam melaksanakan proses pembelajaran. 
Pada pertemuan balikan yakni pertemuan kepala sekolah dan guru yang bertujuan untuk menganalisis hasil tindakan guru serta menetapkan keputusan cara pemecahan masalah pembelajaran yang dialami guru. Dalam pertemuan balikan kepala sekolah harus banyak mendengar apa yang disampaikan guru, memberikan komentar kepada guru pada saat-saat diperlukan, menghargai usaha guru memberikan dukungan, jangan banyak memberi nasihat dan saran terlebih lagi memberi kritik tajam. Tindak lanjut dari pertemuan balikan adalah kepala sekolah membina guru bersangkutan agar selalu memperbaiki kekurangan dirinya dalam melaksanakan pembelajaran. Oleh sebab itu guru disarankan untuk kembali mempraktekan tindakan pembelajaran dalam upaya memperbaiki kekurangan dirinya dalam melaksanakan pembelajaran. Sebaliknya kepala sekolah memantau dan menilai perubahan-perubahan yang terjadi pada guru yang bermasalah dalam melaksanakan pembelajaran.

Secara umum pelaksanaan supervisi akademik sesuai dengan rencana. Hasil observasi yang dilakukan terhadap kompetensi guru kemudian dianalisis dan menghasilkan nilai rata-rata sebesar 68,06 dengan persentase sebesar 68,06\% yang berarti tingkat kompetensi guru dalam proses pembelajaran sebesar $68,06 \%$ berada pada rentangan 65-74 yang tergolong cukup.

Dilihat dari hasil observasi terhadap kompetensi guru dalam proses pembelajaran dalam kategori cukup. Kendala yang dihadapi guru pada siklus I adalah peranan guru tampak masih dominan, sehingga siswa tidak terlalu aktif dalam proses pembelajaran. Guru jarang mengaitkan materi dengan kehidupan siswa sehari-hari, penilaian yang dilakukan guru hanya terfokus pada penilaian akhir pelajaran, guru tidak menilai proses yang dilakukan siswa. Dalam berkomunikasi dengan siswa, tampak guru masih menggunakan gaya bahasa yang kaku. Kendala-kendala ini dibahas bersama guru untuk mencari solusinya, agar pada siklus II hal tersebut tidak terjadi lagi.

Sebelum dilaksanakannya tindakan pada siklus II untuk mengamati keefektifan pelaksanaan supervisi akademik dalam rangka meningkatkan kompetensi guru dalam proses pembelajaran, terlebih dahulu peneliti melakukan diskusi dengan guru-guru. Pertemuan ini membahas tetang hasil refleksi dari kegiatan pada siklus I. Pada kesempatan tersebut, peneliti kembali menyampaikan kelebihan ataupun kekurangan dari pada pelaksanaan siklus I. Melalui diskusi kemudian disepakati untuk melakukan perbaikan-perbaikan dari kelemahan ataupun kekurangan tersebut, serta memperhatikan dan mempertahankan hal-hal yang sudah terlaksana pada siklus pertama.

Dalam kegiatan ini juga, guru-guru kemudian kembali bekerja untuk menyiapkan materi ajar, menyusun rancangan pembelajaran, serta menyiapkan media dan alat peraga pembelajaran yang diperlukan. Hasil observasi yang dilakukan terhadap kompetensi guru dalam proses pembelajaran pada siklus II kemudian dianalisis dan diperoleh rata-rata sebesar 78,06 dengan persentase kompetensi guru dalam proses pembelajaran sebesar $78,06 \%$ yang berarti tingkat kompetensi guru dalam proses pembelajaran sebesar 78,06\% berada pada rentangan 75-89 yang tergolong baik.

Upaya yang dilakukan guru dalam melaksanakan pembelajaran pada siklus II menunjukan peningkatan-peningkatan sesuai dengan harapan peneliti. Setelah mencermati dari hasil observasi terhadap kompetensi guru dalam proses pembelajaran secara keseluruhan menampakan hasil dalam kategori baik. Hal ini menunjukkan bahwa penerapan supervisi akademik yang dilakukan cukup efektif. Oleh karena indikator keberhasilan sudah tercapai maka siklus dicukupkan sampai siklus II.

Berdasarkan hasil analisis data dari prasiklus sampai ke siklus II dapat dilihat pada rekap hasil penelitian pada tabel 02 .

Tabel 02 Rekap Hasil Penelitian

\begin{tabular}{|c|c|c|c|}
\hline No & Siklus & Rata-Rata & Rata-Rata Persen \\
\hline 1 & Pra & 65,19 & 65,19\% (Cukup) \\
\hline 2 & I & 68,06 & $68,06 \%$ (Cukup) \\
\hline 3 & II & 78,06 & $78,06 \%$ (Baik) \\
\hline
\end{tabular}

Berdasarkan hasil analisis data terlihat kemampuan guru SD Negeri 1 Kalibukbuk meningkat dari prasiklus, siklus I, dan siklus II. Pada prasiklus kompetensi guru dalam proses pembelajaran sebesar 65,19 dengan tingkat kemampuan guru sebesar 65,19\% yang tergolong cukup. Untuk meningkatkan kompetensi guru dalam proses pembelajaran dilakukan melalui kegiatan supervisi akademik. Pada siklus I tingkat kompetensi guru dalam proses pembelajaran sebesar 68,06\% berada pada rentangan 65-74 yang tergolong cukup. Kendala yang dihadapi guru pada siklus I adalah peranan guru tampak masih dominan, sehingga siswa tidak terlalu aktif dalam proses pembelajaran. Guru jarang mengaitkan materi dengan kehidupan siswa sehari-hari, penilaian yang dilakukan guru hanya terfokus pada penilaian akhir pelajaran, guru tidak menilai proses yang dilakukan siswa. Dalam berkomunikasi dengan siswa, tampak 
guru masih menggunakan gaya bahasa yang kaku. Kendala-kendala ini dibahas bersama guru untuk mencari solusinya, agar pada siklus II hal tersebut tidak terjadi lagi.

Pada siklus II tingkat kompetensi guru dalam proses pembelajaran sebesar $78,06 \%$ berada pada rentangan 75-89 yang tergolong baik. Secara umum pelaksanaan tindakan pada siklus II sudah berjalan lebih baik dibandingkan dengan siklus I.

Beberapa indikator yang pencapaiannya masih kurang disklus I sudah dapat ditingkatkan. Guru sudah bisa mengatasi kendala yang dihadapi dengan cara berdiskusi dengan kepala sekolah selaku peneliti. Dilihat dari peningkatan kompetensi guru dalam proses pembelajaran dari prasiklus sampai siklus II menunjukkan bahwa implementasi supervisi akademik sangat efektif. Melalui penerapan supervisi akademik guru dapat berdiskusi dengan kepala sekolah tentang kendala-kendala yang dihadapi, sehingga guru mampu melaksanakan proses pembelajaran yang efektif.

Supervisi akademik bertujuan untuk memberikan bantuan serta pembinaan terhadap guru yang memiliki kesulitan pada saat melakukan pembelajaran dikelas sehingga dapat membantu untuk meningkatkan kinerja guru. Kegiatan supervisi akademik merupakan salah satu tujuan untuk mengembangkan proses pembelajaran di kelas serta meningkatkan kinerja guru. Hal ini sesuai dengan pendapat Atmodiwiryo, (2011) tujuan supervisi akademik dalam meningkatkan kinerja guru adalah membantu guru untuk memperbaiki mutu mengajar guru dan membina professionalitas kinerja guru.

Fungsi dari pelaksanaan supervisi akademik dalam meningkatkan kinerja guru adalah sebagai sumber informasi bagi pengembangan profesionalisme kinerja guru dengan melihat dari hasil pelaksanaan supervisi akademik tersebut melalui perbaikan dan saling berkesinambungan dari rencana tindak lanjut setelah supervisi dilakukan, diantaranya adalah (1) kepala sekolah mengupayakan usahausaha perlu dilakukan untuk meningkatkan kinerja guru, dan meningkatkan kualitas proses pembelajaran, (2) Dapat memberikan kemajuan untuk guru itu sendiri, (3) Kepala sekolah memberikan motivasi terhadap guru dalam melaksanakan kinerjanya, (4) Memberikan bimbingan untuk meningkatkan pembelajaran bagi siswa, sedangkan untuk guru tentunya memperbaiki cara mengajar yang kurangkurang, dan yang terakhir (5) untuk memperbaiki kinerja guru, sehingga guru sebelum melaksanakan pembelajaran berlangsung harus memahami materi yang akan disampaikan.

Penelitian tentang penerapan supervisi akademik dilakukan oleh (Tama, 2009)di SMP Negeri 1 Kuta Utara dengan populasi dan sampel 80 orang (penelitian sensus) ditemukan bahwa supervisi akademik mempunyai pengaruh yang lebih baik dibandingkan sebelum diberikan supervisi akademik terhadap kompetensi pedagogik guru. Salah satu upaya peningkatan profesional mutu kinerja guru adalah melalui supervisi akademik. Pelaksanaan supervisi akademik perlu dilakukan secara sistematis oleh kepala sekolah dan pengawas yang bertujuan memberikan pembinaan kepada guru-guru agar dapat melaksanakan tugasnya secara efektif dan efisien

Hendriyathi, (2012) juga telah menulis artikel tentang Pembinaan Profesional Melalui Supervisi Akademik Sebagai Upaya Peningkatan Mutu Kinerja Guru Pada Sekolah Dasar Santo Yoseph 1 Denpasar. Kaitan artikel tersebut dengan penelitian ini adalah sama-sama berpendapat bahwa supervisi akademik merupakan salah satu sumber acuan dalam pengembangan profesional tenaga kependidikan(khususnya guru), melalui efektifitas dimensi kompetensi supervisi akademik oleh kepala sekolah dan pengawas sekolah,denganmemaksimalkan kegiatan supervisi akademik diharapkan tenaga guru dapat meningkatkan pengetahuan dan ketrampilan dalam proses pembelajaran. Semakin sering dilaksanakan supervisi akademik oleh kepala sekolah dan pengawas sekolah terhadap guru dapat meningkatkan secara signifikan kualitas kinerja guru dalam proses pembelajaran.

\section{Simpulan dan saran}

Berdasarkan pemaparan dan hasil analisis pada bagian sebelumnya, maka dapat disimpulkan bahwa penerapan supervisi akademik dapat meningkatkan kompetensi guru dalam proses pembelajaran di SD Negeri 1 Kalibukbuk semester II tahun pelajaran 2019/2020. Hal ini terlihat dari peningkatan kompetensi guru dalam proses pembelajaran yaitu pada prasiklus tingkat kompetensi guru dalam proses pembelajaran sebesar 65,19\% yang tergolong cukup, pada siklus II menjadi 68,06\% yang tergolong cukup, dan pada siklus II menjadi 78,06\% yang tergolong baik.

Berdasarkan kesimpulan hasil penelitian maka disarankan kepada guru-guru, agar lebih memahami siswa karakteristik siswa dan materi, agar bisa melaksanakan proses pembelajaran dengan optimal. Kepada Kepala Sekolah, supervisi yang dilakukan hendaknya berkelanjutan, agar kompetensi guru dapat ditingkatkan. 


\section{Daftar Rujukan}

Agung, A. A. G. (2010). Metodologi Penelitian Pendidikan, Suatu Pengantar. (FIP Undiksha Singaraja, Ed.). Singaraja.

Atmodiwiryo, S. (2011). Manajemen Pengawasan dan Supervisi Sekolah. Jakarta: PT. Ardadizya jaya.

Dirjen PMPTK. (2008). Metode dan Teknik Supervisi Tahun 2008. Jakarta: Depdiknas.

Hendriyathi. (2012). Pembinaan Profesional Melalui Supervisi Akademik Sebagai Upaya Peningkatan Mutu Kinerja Guru Pada SD Santo Yoseph I Denpasar.

Istianah, I. (2019). Implementasi Program Supervisi Akademik Kepala Sekolah Dalam Meningkatkan Profesionalisme Guru di SMAN 1 Cikarang Utara dan MAN Kabupaten Bekasi. Rasi Pendidikan, Volume 26 Issue 1, April 2019 H, 26(1).

Lalupanda, E. M. (2019). Implementasi Supervisi Akademik Untuk Meningkatkan Mutu Guru. Jurnal Akuntabilitas Manajemen Pendidikan, 7(1).

Masnun, B. (2017). Mengefektifkan Supervisi Akademik Dalam Upaya Meningkatkan Kompetensi Guru Kelas Dalam Proses Pembelajaran Semester Satu Tahun Pelajaran 2016/2017 SD Negeri 27 Ampenan. JIME, 3(1).

Messi, Wiwin Anggita Sari, \& M. (2018). Pelaksanaan Supervisi Akademik Pengawasan Sekolah Sebagai Upaya Peningkatan Profesionalisme Guru. Jurnal Manajemen, Kepemimpinan, Dan Supervisi Pendidikan, 3(1).

Riyanto, M. (2015). Manajemen Kepala Sekolah Dalam Melaksanakan Supervisi Akademik Di SMA Negeri 5 Lubuklinggau. Jurnal Manajer Pendidikan, 9(1).

Sagala, S. (2020). Supervisi Pembelajaran dalam Profesi Pendidikan. Bandung: Alfabeta.

Sugiyanti \& Sabar Narimo. (2016). Pengelolaan Supervisi Akademik oleh Kepala Sekolah di SD Negeri 6 Putatsari Grobogan. Jurnal Managemen Pendidikan, 11(2).

Sukarmen. (2018). Pelaksanaan supervisi akademik oleh kepala sekolah dalam meningkatkan kompetensi profesional guru. Jurnal Riset Tindakan Indonesia, 3(2).

Suradi, A. (2018). Supervisi Akademik Kepala Sekolah Terhadap Kinerja Guru Pendidikan Agama Islam Di Sekolah Dasar Negeri 79 Kota Bengkulu. Jurnal Pendidikan Dasar Islam, 5(1).

Tama, I. K. (2009). Pengaruh Pelaksanaan Supervisi Akademik Tehadap Penguasaan Kompetetensi Pedagogik Ditinjau dari Etos Kerja Pada Guru SMP Negeri 1 Kuta Utara Tahun 2008/2009. Tesis Pasca SarjanaUniversitas Pendidikan Ganesha Singaraja.

Usman. (2018). Upaya Meningkatkan Kompetensi Guru Binaan Dalam Proses Pembelajaran Melalui Supervisi Akademik Di Kelas Semester Satu Tahun Pelajaran 2017/2018 SD Negeri 39 Mataram. JISIP, 2(1).

Zulfikar, Yusrizal, \& S. I. (2017). Supervisi Akademik Oleh Kepala Sekolah dalam Meningkatkan Kompetensi Profesional Guru SD Negeri 2 Calang Kabupaten Aceh Jaya. Jurnal Magister Administrasi Pendidikan, 5(3). 